\title{
Evaluation and comparison of the effect of cigarette smoking, alcohol, paan and Indian spices on the colour stability and surface roughness of two types of dental ceramics - an in vitro study
}

\section{Ocena i porównanie wpływu palenia papierosów, alkoholu, żucia betelu oraz przypraw indyjskich na stabilność koloru i chropowatość powierzchni dwóch rodzajów ceramiki dentystycznej - badania in vitro}

\author{
Sushil Kar', Sandeep Yadav', Arvind Tripath ${ }^{2}$ \\ ${ }^{1}$ Faculty of Dentistry, MKCG Medical College, Berhampur, Odisha, India \\ 2 Department of Prosthodontics, Saraswati Dental College and Hospital, Lucknow, Uttar Pradesh, India \\ Head: Professor Arvind Tripath
}

KEY WORDS:

roughness, colour change, stainings, habits

\section{Summary}

Introduction. Chewing of paan is a common habit among Indian populations and very few studies have been conducted about their impact on aesthetic restorations.

Aim of the study. To evaluate the colour stability and surface roughness of dental ceramics after exposure to different oral habits.

Material and methods. Fifty flat cylindrical nickel-chromium metal bases were baked with Vita VMK Master and Ceramco-3. The samples were exposed to alcohol, paan, Indian spices, artificial saliva and cigarettes. Surface profilometer and reflectance spectrophotometer Lambda 950 were used to measure the surface roughness and colour change of specimens, respectively. Repeated measures analysis of variance (ANOVA), Newman-Keuls test and Bonferroni post hoc tests were used to test the significance and possible interactions of each factor.
HASŁA INDEKSOWE:

chropowatość, zmiana kolorystyczna, przebarwienia, nawyki

\section{Streszczenie}

Wprowadzenie. Żucie betelu jest powszechnym zwyczajem $w$ populacji indyjskiej, jednak przeprowadzono niewiele badań dotyczacych wptywu tej czynności na estetyczne uzupetnienia protetyczne.

Cel pracy. Celem badania byta ocena stabilności koloru i chropowatości powierzchni ceramiki dentystycznej po ekspozycji na różne używki majace wptyw na stan jamy ustnej.

Materiat i metody. Pięćdziesiąt płaskich cylindrycznych próbek niklowo-tytanowych zostato pokryte porcelana Vita VMK Master $i$ Ceramco-3, a nastepnie wypalano $w$ piecu do ceramik dentystycznych. Tak przygotowane próbki poddano działaniu alkoholu, betelu, indyjskich przypraw, sztucznej śliny i papierosów. Do pomiaru chropowatości powierzchni $i$ zmiany koloru próbek zastosowano profilometr powierzchni $i$ spektrofotometr Lambda 950. Analiza wariancji z powtórzonymi pomiarami (ANOVA), test New- 
Results. The mean surface roughness and colour change were the highest in paan and the lowest in artificial saliva in both groups. Ceramco-3 was found to be rougher and less colour stable than Vita VMK after all the exposures and were found to be statistically significant $(p<0.05)$.

Conclusions. Both Vita VMK Master and Ceramco-3 produced maximum colour change with paan stain but surface roughness of Ceramco-3 was found to be comparatively higher in Ceramco-3 than in Vita VMK.

\section{Introduction}

Ceramics have been proven to be the most aesthetic type of restoration, yet discoloration is one of the primary factors of their failure. ${ }^{1,6}$ Dietary patterns, such as caffeine, tea, red wine, orange juice, soft drinks, food colorants and oral habits such as cigarette smoking and alcoholic beverage drinking have been shown to influence the colour stability of restorative materials. ${ }^{7-11}$ Indian spices, apart from medicinal and cultural importance, also have a staining property and their effect on colour stability and surface roughness is still unknown. ${ }^{12}$ Additionally, paan - a combined preparation of betel leaf with areca nut and tobacco - widely consumed in India because of personal, social, cultural and medicinal attributes, causes considerable changes in the colour of aesthetic restorations. ${ }^{13,14}$ To evaluate the amount of colour change in restorative materials a spectrophotometer has been widely used, which measures the amount of
man-Keuls oraz testy post hoc Bonferroniego zostaty wykorzystane $w$ celu oceny istotności statystycznej oraz możliwych zależności pomiędzy każdym z badanych czynników.

Wyniki. Średnia chropowatość powierzchni oraz zmiana barwy były największe w przypadku betelu, najmniejsze wartości osiagnięto $w$ grupach poddanych działaniu sztucznej śliny. Stwierdzono, iz ceramika Ceramco-3 charakteryzowała się większym stopniem chropowatości niż ceramika Vita VMK we wszystkich grupach poddanych ekspozycji czynników badanych i były to różnice istotne statystycznie $(p<0,05)$.

Wnioski. Zarówno ceramika Vita VMK, jak $i$ Ceramco-3 ulegty największej zmianie kolorystycznej pod wptywem betelu, jednak ceramika Ceramco-3 charakteryzowata się wyższym stopniem chropowatości niż Vita VMK.

light reflected by a surface as a function of wavelength to produce a reflectance spectrum. ${ }^{15}$ Although porcelain is resistant to discoloration, it is essential to consider the type of diet which is consumed by the larger population. Thus, the present study was conducted to compare colour stability and surface topography of two different feldspathic porcelains after cigarette smoking, alcohol, paan and Indian spices using a spectrophotometer and surface profilometer, respectively.

\section{Material and methods}

\section{Preparation of alloy sub-structure}

Fifty nickel-chromium alloy discs having a diameter of $15 \mathrm{~mm}$ and thickness of $1 \mathrm{~mm}$ were fabricated following all the standardized protocols (Figure 1A). An aluminum mold, which had a plunger and a cylinder, was designed and constructed. The plunger was $2 \mathrm{~mm}$ short from the base to provide space of $1 \mathrm{~mm}$ for metal and $1 \mathrm{~mm}$ for dentine 


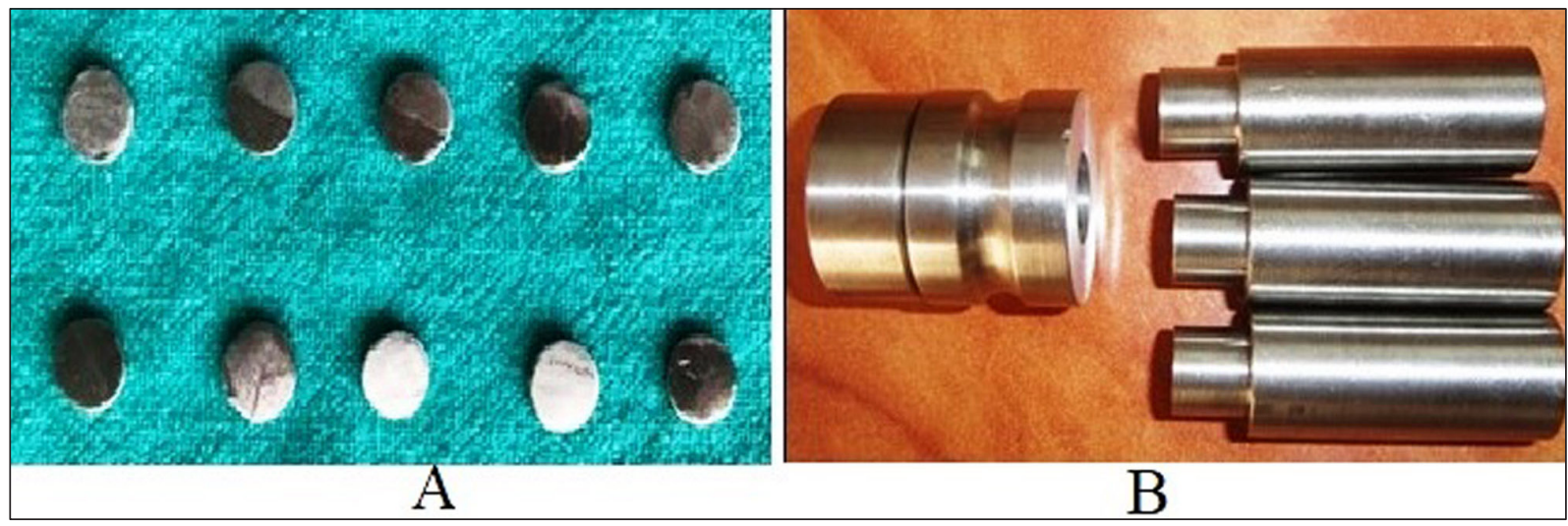

Fig. 1. Ni-Cr alloy samples of $1 \mathrm{~mm}$ thickness (A) and customized cylinder and metal plunger (B).

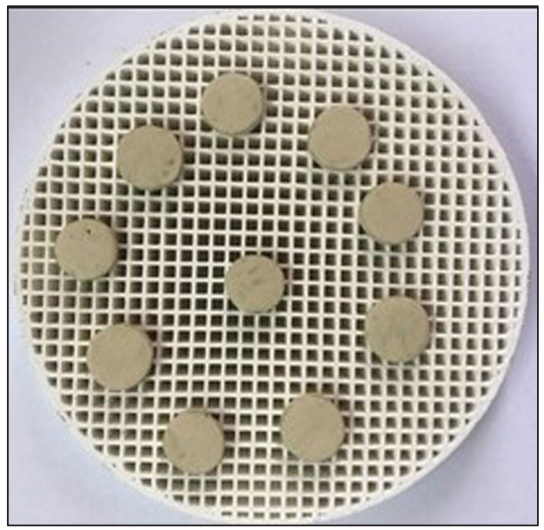

Fig. 2. Fired specimens.

porcelain (Figure 1B). Subsequent to paste opaque application, Vita VMK Master and Ceramco-3 ceramic powder were mixed according to manufacturer instructions and applied to the metal substructures which were condensed in the cylindrical mold with the help of the plunger. After firing, the samples were finished and polished using the necessary tools and measured nine times along their length with a micrometer until the desired thickness was achieved (Figure 2). The samples were ultrasonically cleaned for 5 minutes and then glazed at recommended temperature for 2 minutes.

The samples were categorized into 5 sub-groups according to staining solutions i.e. alcohol, paan, cigarette smoke, Indian

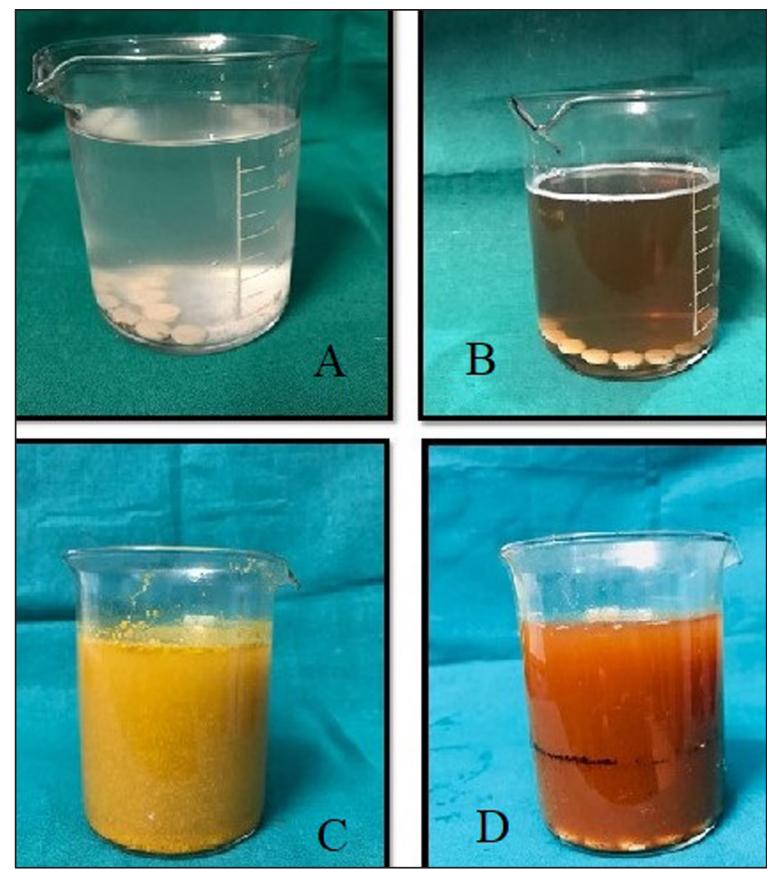

Fig. 3. Specimens in artificial saliva (A), alcohol (B), Indian spices (C) and paan solution (D).

spices \& artificial saliva (control group) with each group containing five samples. The specimens were placed in the respective glass beakers ensuring that both surfaces of the specimens were exposed to the staining solutions uniformly (Figure 3). The duration of immersion in the respective solutions for each sample group was 3 hours per day for 30 days. After the specified time for each day, the 


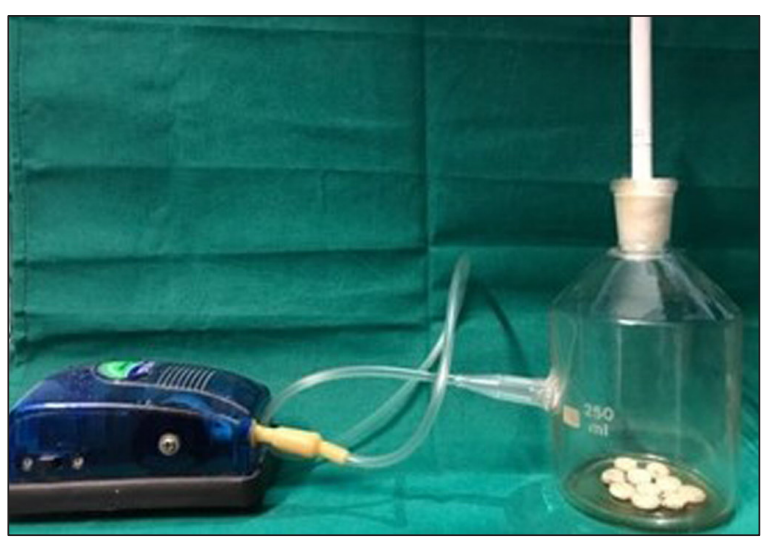

Fig. 4. Custom-made smoking chamber.

specimens were stored in artificial saliva in a plastic container awaiting the next immersion in their respective solutions.

\section{Custom-made smoke chamber}

The fifth groups of test specimens were subjected to the action of cigarette smoke in a customized smoke chamber using a glass beaker. A rubber stopper was fitted with a hole to support one end of the cigarette and a vacuum system that caused a negative pressure to aspirate the smoke released by the cigarette. For active filling of cigarette smoke in the smoke chamber, the outlet was closed and vacuum system was switched on for 2 seconds (puff duration). To maintain passive exhaust of smoke, rubber stopper was removed for 60 seconds before the next smoke cycle was performed, so as to mimic passive exhalation of smoke in vivo. ${ }^{10}$ The test specimens were placed at the base of the glass beaker, so that the greater part of their surface would be exposed to cigarette smoke (Figure 4). For each sample, twenty cigarettes (Classic Mild, ITC) were used, and each cigarette was burnt in a standard time of $10 \mathrm{~min}$. Prior to colour change and surface roughness measurements of each specimen, all the specimens were rinsed with distilled water at $37^{\circ} \mathrm{C}$ and dried with filter paper. The readings were recorded at the end of 30 days.

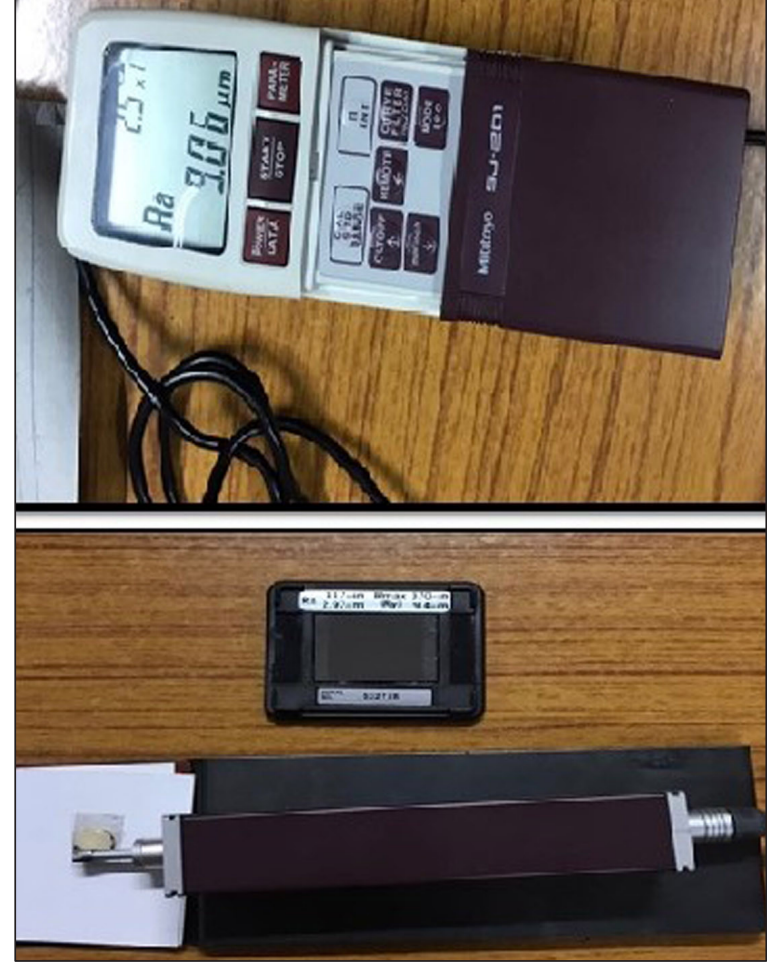

Fig. 5. Surface Profilometer.

There are many reasons as to why an individual becomes addicted to an oral habit. Once indulging in it, it then becomes a part of their life style until any serious health issue arises. So on average a ceramic in the form of a crown or a bridge becomes exposed to those chemicals over a long period of time. Therefore, to get an appreciable outcome, both qualitatively and quantitatively, all the specimens were exposed for such a long time.

\section{Surface Roughness Assessment}

In the present study, a Surface Profilometer (Mitutoyo - SJ-201, Mitutoyo Corp, Kawasaki) was used to measure the surface roughness of each sample. The samples were placed on the testing surface of the surface profilometer and the stylus of the device was positioned directly upon the sample to be tested in the contactmode (Figure 5). 


\section{Colour Assessment}

The authors have used a reflectance spectrophotometer Lambda 950 (Perkin Elmer, Watham MA) to measure the colour change for each specimen. The readings obtained were interpreted through CIE L*a* $b^{*}$ parameters. A customized positioning jig made from selfcuring acrylic resin was fabricated to obtain consistent and standardized orientation of specimen for colour measurement. The spectrophotometer was calibrated to white and green ceramic tiles supplied by the manufacturer, and measurements were performed using a neutral gray background. As the final judgment of colorimetric evaluation is visual, it has been necessary to establish a relationship between visual and instrumental analysis. In the classic work of Kuehni \& Marcus, an average colour difference of up to $3.7 \Delta \mathrm{E}$ was considered acceptable by measurement in an extended visual rating scale (EVRSAM). ${ }^{16}$

\section{Statistical analysis}

SPSS Version 17.0 was used for statistical analysis. To test the significance and possible interactions of each factor, repeated measures analysis of variance (ANOVA) were used. Newman-Keuls post hoc test was used to calculate differences between group means and Bonferroni post hoc tests were applied to each factor where significant differences between unit factors were found. The level of significance ( $p$-value) for all statistical testing was set at $\mathrm{a} \leq 0.05$.

\section{Results}

The present study compared the effects of cigarette smoking, alcohol, paan and Indian spices on the colour stability and surface roughness of two types of dental ceramics. The surface roughness was measured in Ra $\Delta \mathrm{L}$ micrometer $(\mu \mathrm{m})$, and colour change assessed using $\Delta \mathrm{E}$ values.

\section{Surface roughness}

After exposure to five different staining solutions i.e. artificial saliva, Indian spices, alcohol, cigarette smoking and paan, the mean surface roughness was found to be the highest in paan and the lowest in artificial saliva and in all exposures, the surface roughness was higher in Ceramco 3 than in vita VMK. The difference in mean surface roughness for each group between exposures was significant $(p<0.05)$ but no statistical differences were found on comparing the surface roughness with artificial saliva $(\mathrm{p}>0.05)$ (Table 1). Similarly,

Table 1. Mean surface roughness and comparison of difference in mean surface roughness between groups

\begin{tabular}{|l|c|c|c|c|}
\hline \multirow{2}{*}{ Exposure } & \multirow{2}{*}{ Ceramco 3 } & \multirow{2}{*}{ vita VMK } & Comparaison (Ceramco 3 vs. vita VMK) \\
\cline { 4 - 5 } & & & Mean diff. & Mean diff. \\
\hline Artificial saliva & $1.14 \pm 0.21$ & $1.09 \pm 0.20$ & 0.06 & 0.06 \\
\hline Indian spices & $3.15 \pm 0.34$ & $2.78 \pm 0.25$ & 0.37 & 0.37 \\
\hline Alcohol & $2.91 \pm 0.14$ & $2.61 \pm 0.41$ & 0.30 & 0.30 \\
\hline Cigarette smoking & $3.87 \pm 0.44$ & $3.41 \pm 0.34$ & 0.46 & 0.46 \\
\hline Paan & $4.65 \pm 0.69$ & $4.31 \pm 0.75$ & 0.33 & 0.33 \\
\hline
\end{tabular}


Ta b 1 e 2. Comparison of difference in mean surface roughness between exposures by Newman-Keuls test (each group)

\begin{tabular}{||l|c|c|c|c|}
\hline \multirow{2}{*}{\multicolumn{1}{|c|}{ Comparison }} & \multicolumn{2}{c|}{ Ceramco 3 } & \multicolumn{2}{c|}{ Vita VMK } \\
\cline { 2 - 5 } & Mean diff. & $\mathrm{p}$ value & Mean diff. & $\mathrm{p}$ value \\
\hline Artificial saliva vs. Indian spices & 2.00 & 0.024 & 1.69 & 0.048 \\
\hline Artificial saliva vs. Alcohol & 1.76 & 0.037 & 1.52 & 0.049 \\
\hline Artificial saliva vs. Cigarette smoking & 2.73 & 0.003 & 2.33 & 0.014 \\
\hline Artificial saliva vs. Paan & 3.50 & $<0.001$ & 3.23 & 0.001 \\
\hline Indian spices vs. Alcohol & 0.24 & 0.693 & 0.17 & 0.780 \\
\hline Indian spices vs. Cigarette smoking & 0.72 & 0.463 & 0.63 & 0.719 \\
\hline Indian spices vs. Paan & 1.50 & 0.130 & 1.53 & 0.155 \\
\hline Alcohol vs. Cigarette smoking & 0.96 & 0.398 & 0.80 & 0.671 \\
\hline Alcohol vs. Paan & 1.74 & 0.081 & 1.70 & 0.115 \\
\hline Cigarette smoking vs. Paan & 0.78 & 0.414 & 0.90 & 0.312 \\
\hline
\end{tabular}

Ta b 1 e 3. Mean colour change and comparison of difference in mean colour change between groups

\begin{tabular}{|l|c|c|c|c|}
\hline \multirow{2}{*}{\multicolumn{1}{c|}{ Exposure }} & \multirow{2}{*}{ Ceramco 3 } & \multirow{2}{*}{ Vita VMK } & \multicolumn{2}{c|}{ Comparaison (Ceramco 3 vs. Vita VMK) } \\
\cline { 4 - 5 } & & & Mean diff. & Mean diff. \\
\hline Artificial saliva & $0.72 \pm 0.22$ & $0.65 \pm 0.20$ & 0.07 & 0.07 \\
\hline Indian spices & $2.53 \pm 0.33$ & $2.08 \pm 0.37$ & 0.44 & 0.44 \\
\hline Alcohol & $2.11 \pm 0.17$ & $1.85 \pm 0.17$ & 0.26 & 0.26 \\
\hline Cigarette smoking & $2.70 \pm 0.43$ & $2.21 \pm 0.28$ & 0.49 & 0.49 \\
\hline Paan & $2.81 \pm 0.66$ & $2.30 \pm 0.31$ & 0.51 & 0.51 \\
\hline
\end{tabular}

the difference in mean surface roughness between the groups after each exposure was not significant $(\mathrm{p}>0.05)$, although it was comparatively lower in artificial saliva (Table 2).

\section{Colour change}

The colour change of two groups (Ceramco 3 and vita VMK) showed similar results like surface roughness with the highest in paan and the lowest in artificial saliva (artificial saliva
$<$ alcohol $<$ Indian spices $<$ cigarette smoking $<$ paan) and for all exposures, it was higher in Ceramco 3 than in vita VMK (Table 3). The difference in mean colour change between the exposures for each group Newman-Keuls test showed statistically significant difference $(\mathrm{p}<0.05$ or $\mathrm{p}<0.01)$ (Table 4). Higher colour change was observed in all exposures when compared to artificial saliva in both groups (Figure 6). 
T a b l e 4. Comparison of difference in mean colour change between exposures (each group)

\begin{tabular}{||l|c|c|c|c|}
\hline \multirow{2}{*}{\multicolumn{1}{|c|}{ Comparison }} & \multicolumn{2}{c|}{ Ceramco-3 } & \multicolumn{2}{c|}{ Vita VMK } \\
\cline { 2 - 5 } & Mean diff. & $\mathrm{p}$ value & Mean diff. & $\mathrm{p}$ value \\
\hline Artificial saliva vs. Indian spices & 1.81 & 0.011 & 1.44 & 0.026 \\
\hline Artificial saliva vs. Alcohol & 1.39 & 0.034 & 1.20 & 0.047 \\
\hline Artificial saliva vs. Cigarette smoking & 1.98 & 0.005 & 1.57 & 0.029 \\
\hline Artificial saliva vs. Paan & 2.09 & 0.003 & 1.66 & 0.024 \\
\hline Indian spices vs. Alcohol & 0.42 & 0.826 & 0.24 & 0.627 \\
\hline Indian spices vs. Cigarette smoking & 0.17 & 0.727 & 0.13 & 0.964 \\
\hline Indian spices vs. Paan & 0.29 & 0.828 & 0.22 & 0.970 \\
\hline Alcohol vs. Cigarette smoking & 0.59 & 0.745 & 0.37 & 0.876 \\
\hline Alcohol vs. Paan & 0.71 & 0.699 & 0.46 & 0.881 \\
\hline Cigarette smoking vs. Paan & 0.11 & 0.816 & 0.09 & 0.853 \\
\hline & & & & \\
\hline
\end{tabular}

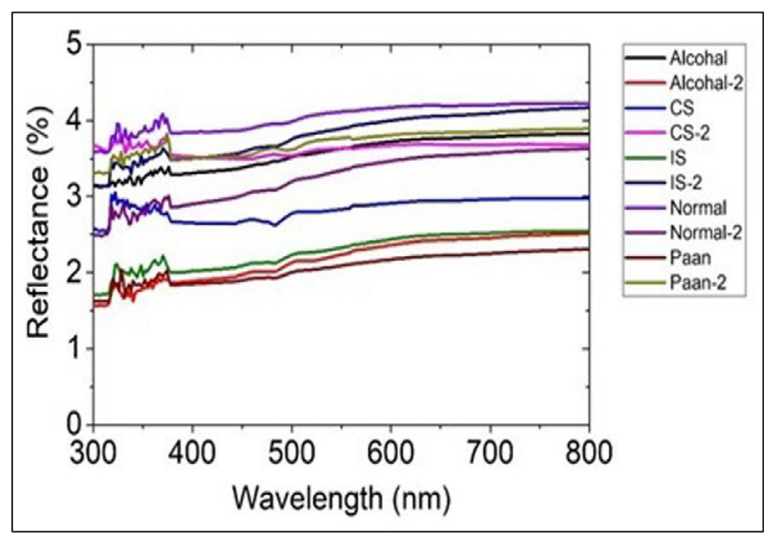

Fig. 6. Reflectance percentage and wavelength graph.

\section{Discussion}

Although porcelain restorations are considered to be colour stable, yet discoloration is one of the primary factors for failure of aesthetic restorations. Discoloration of porcelain may be due to intrinsic or extrinsic factors. Dietary habits like consumption of spices, alcoholic drinks, chewable tobacco and paan (generally practised in Southeast Asian countries) also have an effect on surface roughness and colour stability of the ceramics. Surface roughness of porcelain is influenced by the size, distribution and volume of ceramic particles and the type of finishing and polishing procedures used. ${ }^{17,18}$ Sarac et al. have suggested that the smaller the particle size, the better the polishing, and consequently there would be less colour change. ${ }^{19}$ The present study was conducted on fifty samples of two different brands of dental ceramics: 25 samples of vita VMK Master and 25 samples of Ceramco-3. Surface roughness was evaluated on the $30^{\text {th }}$ day and comparison was made with artificial saliva as the control group. It was observed that the profilometer readings of surface roughness were maximum with paan, followed by cigarette smoke, and the lowest with artificial saliva.

Paan consists of important polyphenolic constituents of areca nut i.e. caffeic acid, ferulic acid, catchu-tannic acid and nitrosamine acids of tobacco. Very few studies have been done 
on the effect of paan on the surface roughness and colour stability of dental ceramics. In the present study, paan showed the maximum surface roughness when compared with artificial saliva with a mean difference of 3.50 \& 3.23 on Ceramco-3 and Vita VMK Master, respectively. When intra group comparisons were made with artificial saliva, the value was found to be statistically significant $(\mathrm{p}<0.001)$. Higher acidic content of catchu-tannic acid and acidic compounds of areca nut could be responsible for surface roughness to such an extent. $^{14}$

The acids produced during different phases of cigarette smoking are formic acid, acetic acid, propionic acid, nitric acid and carboxylic acid. The acids present in non-volatile nitrosamine in tobacco smoke are butyric acid and $\mathrm{N}$-nitrosopipecolic acid. Continuous chewing of tobacco products and repeated smoking breaks the salivary buffering action and reduces the $\mathrm{pH}$ level which tends to abrade the glazed ceramic surface over a period of time. ${ }^{20}$ The mean difference found between cigarette smoke with artificial saliva, alcohol, Indian spices, paan were 2.73, 0.96, 0.72, 0.78 in Ceramco-3 \& 2.33, 0.80, 0.63,0.90 in Vita VMK master, respectively. Kukiattrakoon et al. conducted a study to find the effect of acids on four different types of ceramics, namely Vitadur Alpha, IPS Empress Esthetic, VMK 95 and in IPS e.max Ceram. Vitadur Alpha revealed the greatest degradation after immersion in 4\% acetic acid. The result showed that alumina crystals in Vitadur Alpha had the least durability compared with leucite crystals in IPS Empress Esthetic and VMK 95 and fluorapatite crystals in IPS e.max Ceram. Leucite and fluorapatite crystals appeared to have comparable durability. ${ }^{8}$

Kamala $K R$ et al. found that all ceramic glazed and polished surfaces were not affected after exposure to acidic solutions at significant level. However, Coca-Cola produced higher surface roughness when compared to other acidic solutions tested. ${ }^{11}$ These results were in accordance with those of a study by Duymus Z.Y et al., where the highest surface roughness value $(4.46 \pm 2.9 \mu \mathrm{m})$ was identified on Noritake porcelain by lemonade and the lowest surface roughness value $(1.06 \pm 0.56$ $\mu \mathrm{m})$ was identified on Ceramco 3 porcelain by mineral water. ${ }^{21}$ Jain et al. found that coffee produced the maximum staining of ceramic whereas maximum surface roughness was caused by orange juice, which could be due to high titrable acidity. ${ }^{15}$ In the present study, the mean surface roughness between both groups were not found significant $(p>0.05)$, but a higher mean difference of surface roughness was seen when exposed to different staining solutions i.e. paan, cigarette smoke, Indian spices, alcohol when compared to artificial saliva. Paan produced the highest surface roughness value of $4.65 \pm 0.69$ in ceramco-3 $\& 4.31 \pm 0.75$ in vita VMK. When intra group comparison was made between artificial saliva as a control group with other staining solutions i.e. alcohol, Indian spices, cigarette smoke, paan, the values obtained were 1.76, 2.0, 2.73, 3.50 in ceramco-3 \& 1.52, 1.69, 2.33, 3.23 in vita VMK Master, respectively. The values were found statistically significant $(\mathrm{P}<0.001)$ when paan was compared with artificial saliva in intra groups. Higher acidic content of catchutannic acid and acidic compounds of areca nut could be the reason for the surface roughness to such an extent.

Colour change was evaluated through spectrophotometer on the $30^{\text {th }}$ day and comparison was made with artificial saliva as the control group; it was observed that the spectrophotometer readings of colour change of vita VMK master and Ceramco 3 group were maximum with paan, followed by cigarette smoke, and the lowest with artificial saliva. Colour change generally occurs for three reasons: (1) external discolorations due to plaque accumulation and stains; (2) surface 
or sub-surface alterations promoting surface degradation and favouring the penetration and reaction of coloring agents and (3) intrinsic discolorations due to physicalchemical reactions in the deep portions of the restorative material. ${ }^{5,6,8,12-14}$ Nevertheless, there are few studies in the literature about the effect of cigarette smoke on aesthetic restorative materials. When comparison was made between artificial saliva with paan, cigarette smoking, alcohol and Indian spices, the mean difference was $2.09,1.98,1.39 \&$ 1.81 on ceramco 3 and $1.66,1.57,1.20,1.44$ on vita $\mathrm{VMK}$, respectively.

Ghahramanloo et al. found that Porcelain (vita VMK 95) was more resistant to discoloration than reinforced composite resin (GC Gradia). They concluded that acrylic teeth showed a higher degree of colour change, and that the amount of colour change for each group increased proportionally with time. The reason for this difference could possibly be attributed to the extended time period of immersion (90 days) and there was likelihood of a slow breakdown at matrix filler interface because of water sorption over an extended period of time. ${ }^{22}$ Bindal $P$ et al. conducted a study on the staining characteristics of chewable tobacco, turmeric and coffee. The colour ingredient of chewable tobacco is a mixture of butyl rubber and microcrystalline wax. The $\Delta \mathrm{E}$ values obtained from their study confirmed that chewable tobacco showed overall higher staining ability compared to coffee and turmeric. ${ }^{9}$ In the present study, paan shows higher colour changes than Indian spices, as chewable tobacco is a major constituent of paan and imparts more colour change than other agents. Atay et al. investigated the effect of porcelain treatment technique on colour change of feldspathic porcelain before and after exposure to distilled water, coffee, red wine and cola, and concluded that immersion time and type of surface treatment were significant factors for colour stability of feldspathic porcelain. ${ }^{23}$

When the mean colour change between the exposures was compared, the result showed significant changes $(p<0.05)$. Higher mean difference of colour change was seen when exposed to different staining solution i.e. alcohol (0.26), Indian spices (0.44), cigarette smoke (0.49), paan (0.51) when compared to artificial saliva (0.07). The $\mathrm{P}$ value was found significant. When comparison was made for the difference in mean colour change of both groups i.e. vita VMK master \& Ceramco -3, Newmans-kuels analysis showed values which did not differ significantly ( $p>0.05)$. The $\Delta \mathrm{E}$ change between the groups after all exposures was $10.1 \%, 17.5 \%, 12.4 \%, 18.0 \%$ and $18.1 \%$ for artificial saliva, Indian spices, alcohol, cigarette smoke \& paan, respectively and was found statistically the same.

\section{Limitations of the study}

The following limitations can be drawn from the study:

1. Factors like titratability, chemical nature, and temperature of all the liquids should also be considered.

2. Natural buffering capacity of saliva present in the oral cavity has influence on the $\mathrm{pH}$ of immersion liquids, and should have been considered in the present invitro study.

3. Any minor distortion of wax patterns and release of internal stresses during ceramic firing were not considered.

\section{Conclusion}

In the present study, both Vita VMK Master and Ceramco-3, after immersion in different staining solutions, showed minimum colour change (i.e. maximum colour stability) in artificial saliva, alcohol, Indian spices, cigarette smoke, but maximum colour change in paan. 
The surface roughness of Cermco-3 was found to be relatively higher in comparison to Vita VMK Master.

\section{References}

1. McLean JW: The science and art of dental ceramics (Vol 1). The nature of dental ceramics and their clinical use. Chicago: Quintessence Punishing Co; 1979. p. 115-82.

2. Douglas Duane R: Color stability of newgeneration indirect resins for prosthodontic application. J Pros Dent 2000; 83: 166-170.

3. Chiche GJ, Pinault A: Esthetics of anterior fixed prosthodontics. Chicago; Quintessence Publishing Co, 1994. p. 110.

4. McLean JW: The science and art of dental ceramics. Oper Dent 1991; 16: 149-156.

5. Kroeze HJ, Plasschaert AJ, van't Hof $M A$, Truin GJ: Prevalence and need for replacement of amalgam and composite restoration in Dutch adults. J Dent Res 1990; 69: 1270-1274.

6. Singh K, Suvarna S, Agnihotri Y, Sahoo S, Kumar Prince: Color stability of aesthetic restorative materials after exposure to commonly consumed beverages, A systematic review of literature. Eur J Prosthodent 2014; 2: 15-22.

7. De Souza M, Wasilewski A, Takahashi M, Kirsten A, De Souza: Effect of cigarette smoke, whiskey on color stability of dental composite. Am J Dent 2010; 23: 4-8.

8. Boonlert Kukiattrakoon, Chanothai Hengtrakool, Ureporn Kedjarune-Leggat: Effect of Acidic Agents on Surface Roughness of Dental Ceramics. Dent Res J 2011; 8: 6-15.

9. Bindal P, Bindal U, Dabbagh A, Ramanathan $A$, Ginjupalli $K$ : Comparative Effects of Turmeric, Coffee, and Chewable Tobacco on the Color Stability of Tooth-colored Restorative Materials. J Dent Oral Hyg 2015; 3: 59-67.
10. Patil SS, $M \quad R \quad D$, Gujjari AK: Effect of cigarette smoke on acrylic resin teeth. J Clin Diagn Res 2013; 7: 2056-2059.

11. Kamala KR, Annapurni $H$ : Evaluation of surface roughness of glazed and polished ceramic surface on exposure to fluoride gel, bleaching agent and aerated drink: An in vitro study. J Indian Prosthodont Soc 2006; 6: 128132.

12. Kamala Krishnaswamy: Traditional Indian spices and their health significance. Asia Pac J Clin Nutr 2008; 17(S1): 265-268.

13. The World Health Organization IARC Expert Group. "IARC Monographs on the Evaluation of the Carcinogenic Risk of Chemicals to Humans, Tobacco Habits Other than Smoking; Betel-Quid and Areca-nut Chewing; and Some Related Nitrosamines, Lyon" Sep 1985. Vol. 37; IARC, Lyon, France.

14. Ekta SC, Jaya A, Akriti S, Anamika T: A Review: Nutraceuticals Properties of Piper betel (Paan). AJPCT2016; 4: 28-41.

15. Jain C, Bhargava A, Gupta S, Rath R, Nagpal $A$, Kumar P: Spectrophotometric evaluation of the color changes of different feldspathic porcelains after exposure to commonly consumed beverages. J Dent 2013; 7: 172180.

16. Kuehni RG, Marcus RT: An Experiment in Visual Scaling of Small Color Differences. Color Research\&Application 1979; 4: 83-91.

17. Gross MD, Moser JB: Colorimetric study of coffee and tea staining of four composite resins. J Oral Rehab 1977; 4: 318-322.

18. Didier D, Gaetano C, Jacques H, Jean-M: Comparison of the color stability of ten newgeneration composites: An in vitro study (Dental Materials Volume 10, Issue 6, November 1994, 353-362.

19. Whitehead SA, Shearer AC, Watts DC, Wilson $\mathrm{NH}$ : Comparison of methods for measuring surface roughness of ceramic. J Oral Rehabil 1995 22; 421-427. 
20. How Tobacco Smoke Causes Disease: The Biology and Behavioral Basis for SmokingAttributable Disease. A Report of the Surgeon General. Atlanta (GA): Centers for Disease Control and Prevention (US); 2010.

21. Duymus ZY, Ozdogan A and Ulu H: Effect of Different Acidic Agents on Surface Roughness of Feldspathic Porcelain. Open J Stomat 2006; 6: 90-95.

22. Ghahramanloo A, Madani AS, Sohrabi, Sabzevari: An evaluation of color stability of reinforced composite resin compared with dental porcelain in commonly consumed beverages. J California Dental Assoc 2008; 36:673-680

23. Atay A: Effect of colored beverages on the color stability of feldspathic porcelain subjected to various surface treatments. Quintessence Int 2009; 40: e41-8.

Zaakceptowano do druku: 7.12.2020 r.

Adres autorów: Prof. Sushil Kar, Faculty of Dentistry, MKCG Medical College, Berhampur, 760004 Odisha, India

C) Zarząd Główny PTS 2020. 